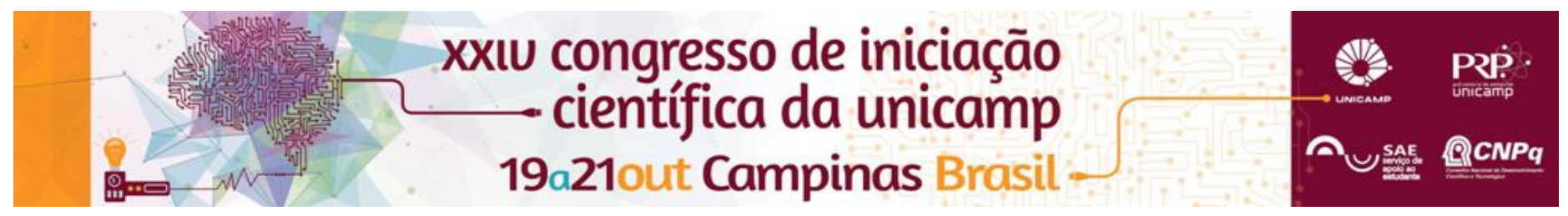

\title{
A POLÍTICA URBANA VANGUARDISTA DO SAAL: REINTRODUZINDO A PARTICIPAÇÃO NO PROCESSO DE PROJETO
}

\author{
Rafael Della Coletta Breda
}

\begin{abstract}
Resumo
A sustentabilidade no ambiente urbano é central nas discussões sobre o futuro das cidades, uma vez que as reivindicações sociais reclamam pelo direito às cidades mais sustentáveis. Pensar a cidade de hoje e do amanhã significa pensar o habitar, sob a perspectiva dos diversos agentes envolvidos e dos muitos reflexos que esse exerce na cidade. Assim, a participação das comunidades é meio fundamental para o processo de projeto, da produção do habitar e da própria cidade sustentável. Contudo, a participação efetiva tem sido pouco valorizada ou relegada a um papel inócuo e fictício. Causa estranhamento pensar a cidade sustentável quando pouco ou nada se considera sobre as pessoas e o lugar onde moram, vivem e trabalham. Se a lógica da sustentabilidade é desenhada sobre os recursos a serem preservados para gerações futuras, como isto pode ser realizado sem o envolvimento da sociedade do presente? Neste sentido, o objetivo desta pesquisa é resgatar experiências bem sucedidas do envolvimento das comunidades em processos participativos para a produção do habitar urbano. Como estudo de caso foram selecionadas as Operações SAAL - Serviço de Apoio Ambulatório Local, realizadas em Portugal. A análise direciona-se para a compreensão das diretrizes do programa, as circunstâncias ambientais e sociais de cada local onde o programa se realizou, a produção arquitetônica e urbanística e as metodologias dos processos participativos realizados. É esperado compreender as condições, métodos e estratégias a fim de identificar possíveis tendências para sua reintrodução na metodologia de projeto habitacional mais sustentável.
\end{abstract}

\section{Palavras-chave:}

Habitação; Processos participativos; Metodologia de projeto.

\section{Introdução}

A participação da população é meio fundamental para o processo de projeto, produção do habitar e da construção de uma cidade sustentável, porém tal envolvimento tem tido papel ineficiente ou até mesmo fictício, assim elaborando uma cidade que não reflete os anseios e necessidades das comunidades em questão. Para a criação de uma cidade sustentável não é somente necessário à atenção aos recursos naturais, mas sim também as pessoas, fazendo a inclusão das populações considerando as relações sociais e a ligação com o espaço a ser trabalhado.

O objetivo deste estudo é resgatar experiências bem sucedidas do envolvimento efetivo das comunidades em processos participativos para a produção do habitar urbano. Nas Operações SAAL foram construídas inúmeras habitações por todo território português. Assim, serão selecionadas unidades de estudo para maior detalhamento das estratégias de projeto.

\section{Resultados e Discussão}

Para as análises foram selecionadas duas regiões de contrastes: Setúbal com o Bairro do Castelo Velho (1), e outra do Porto (2) com os Bairros do Contumil, das Antas, São Vitor, do Leal e Maceda-acácio. A primeira região é mais suburbana, com moradores de diferentes setores produtivos (principalmente composta de pescadores e operários), a segunda, do Porto, possui uma população predominantemente operária e habitante das regiões antigas e centrais da cidade.

A pesquisa foi feita por meio de estudo de caso, a partir das Operações SAAL cuja análise pretendida concentrase para: a compreensão das diretrizes do programa, entendimento das circunstâncias ambientais e sociais de cada local onde o programa se realizou e por fim 0 levantamento da produção arquitetônica e urbanística e dos processos participativos realizados.

O contexto em que as associações de moradores estavam presentes influenciou e de certa forma contribuiu para a produção de um habitar de qualidade; elementos como inquéritos, elaboração de maquetes e até exposição de trabalhos permearam os métodos de estratégia. Também foram identificados alguns fatores que ajudaram no processo de projeto como: a presença de uma sede da associação ou mesmo a convivência com universitários que já realizavam trabalhos acadêmicos nas comunidades. De modo geral as associações foram reais agentes na produção do seu habitar, para Pereira ${ }^{1}$ isto foi fator muito importante e este faz o empoderamento da população.

Porém, apesar de toda a presença da participação e democratização do projeto nas Operações, ainda ficam algumas lacunas devido ao curto tempo, verba e até má formação dos arquitetos.

\section{Conclusão}

O estudo apresenta elementos identificados em algumas das operações SAAL, que auxiliam estruturação da moradia de qualidade para os seus agentes integrais. Para Jacques $^{2}$ a cidade necessita presença da construção coletiva, ou seja, é necessária a participação popular para resolver as questões fundamentais a ela.

\section{Agradecimentos}

Agradeço aos meus familiares, a minha orientadora Silvia Mikami e ao SAE/UNICAMP que contribuiu com o financiamento da pesquisa.

1PEREIRA, G.M. SAAL um programa de habitação popular no processo revolucionário In: História. Porto: FLUP, IV serie, vol. 4, 2014. 